\title{
ANALISIS POTENSI PERTUMBUHAN EKONOMI PROVINSI JAWA TIMUR (SEBELUM DAN SAAT TERJADI PANDEMI COVID-19)
}

\author{
Nurul Assidikiyah'1), Marseto' ${ }^{2)}$, Sishadiyati ${ }^{3)}$ \\ Universitas Pembangunan Nasionall Veteran Jawa Timur, Surabaya, Indonesia ${ }^{1}$ \\ Email: nurulassidikiyah@gmail.com ${ }^{1}$
}

\begin{abstract}
ABSTRAK
Dampak dari adanya pandemi Covid-19 ini menyebabkan adanya penurunan kegiatan ekonomi. Adanya pergeseran struktur perekonomian dalam PDRB sebelum adanya pandemi dan saat terjadi pandemi covid-19 perlu dianalisis lebih jauh untuk mengetahui sektor - sektor apa saja yang menjadi unggulan, andalan, prospektif, dan tertinggal di Provinsi Jawa Timur. Penelitian ini menggunakan data sekunder yang di dapat Badan Pusat Statistik (BPS) Nasional tahun 2015-2020. Dengan menggunakan teknik analisis location quotient (LQ), shift share serta analisis kuadran dapat diketahui bahwa sektor basis di Jawa Timur adalah sektor industri pengolahan, pengadaan air, pengelolaan sampah, limbah dan daur ulang, perdagangan besar dan eceran, penyediaan akomodasi dan makan minum, informasi dan komunikasi. Pada saat sebelum adanya pandemic covid-19 terdapat 14 sektor yang mendorong pertumbuhan PDB Nasional, 10 sektor tumbuh relative cepat, 7 sektor yang memiliki keuntungan lokasional. Sedangkan saat terjadi pandemi Covid-19 terdapat 8 sektor yang mendorong perumbuhan PDB Nasional, 7 sektor tumbuh relative cepat, dan 6 sektor yang memiliki keuntungan lokasional.
\end{abstract}

Kata Kunci: Covid-19, Pertumbuhan Ekonomi, LQ, Shift Share

\begin{abstract}
ABTRACT
The impact of the covid-19 pandemic has been a decrease in economic activity. The economic growth in the PDRB was expected to be further analyzed to determine any sectors that have been economic base, economic sector rapid growth rate and economic sectors have strong competitivenes in the East Java. The study uses a secondary data obtained at the Central Statistics Agency (BPS) National. Using location quotient analysis techniques (lq), shift share and quadrant analysis can be known that the east Java base sector is the industrial processing, water supply, waste and recycling management, large trade and retail, supply of accommodation and drink, information and communication. At the time before covid-19 there were 14 sectors that boosted national GDP growth, 10 sectors grew rapidly, 7 sectors that had local benefits. At the time of the covid-19 pandemic, there are 8 sectors that encourage national GDP growth, 7 sectors grow rapidly, and 6 sectors that have local benefits.
\end{abstract}

Keywords: Covid-19, Economic Growth, LQ, Shift Share 


\section{PENDAHULUAN}

Keadilan Sosial bagi Seluruh Rakyat Indonesia, begitulah bunyi dasar negara Indonesia yaitu Pancasila sila kelima. Untuk mewujudkannya diperlukan upaya peningkatan pembangunan negara Indonesia. Salah satunya yaitu dengan mengembangkan perekonomian negara secara terencana dan terpadu agar tercapainya kemakmuran bagi seluruh rakyat Indonesia. Sehingga Pembangunan merupakan cermin dan bentuk pengamalan Pancasila terutama pada sila kelima. Pembangunan ekonomi daerah merupakan suatu proses dimana pemerintah daerah beserta masyarakatnya mengelola sumber daya yang ada. Setiap pembangunan ekonomi daerah diharapkan dapat merangsang perkembangan ekonomi di wilayah tersebut (Tumangkeng, 2018). Melalui kerjasama antara pemerintah daerah dengan sektor swasta untuk menciptakan lapangan pekerjaan baru sehingga terdapat peningkatan pendapatan per kapita masyarakat. Dengan begitu akan terjadi pertumbuhan ekonomi yaitu proses peningkatan produksi barang dan jasa dalam kegiatan ekonomi masyarakat. Adanya pertumbuhan ekonomi merupakan indikasi keberhasilan dalam pembangunan ekonomi.

Pertumbuhan ekonomi merupakan suatu perkembangan dari sebuah kegiatan ekonomi yang mendorong peningkatan output dalam masyarakat dan mendorong peningkatan kemakmuran serta kesejahteraan masyarakat (Agma, 2015). Salah satu indikator untuk menunjukkan tingkat kemakmuran suatu daerah yaitu dilihat dari data Produk Domestik Regional Bruto (PDRB) atas dasar harga berlaku atau dasar harga konstan. Suatu negara dikatakan mengalami pertumbuhan ekonomi apabila terjadi peningkatan GNP riil di negara tersebut (Margunani, 2002).

Provinsi Jawa Timur merupakan penyumbang terbesar kedua bagi perekonomian Indonesia dengan tingkat pertumbuhan setara dengan tingkat nasional dan provinsi-provinsi besar lainnya di Jawa. Tiga sektor lapangan usaha utama penopang PDRB Jawa Timur secara berturut-turut adalah sektor industri pengolahan (29,03\%), perdagangan (18,18\%), dan pertanian (12,80\%) (BPS Provinsi Jawa Timur, 2019). Secara geografis, Provinsi Jawa Timur memiliki karakteriskik wilayah yang memiliki potensi untuk dikembangkan karena letaknya yang strategis, berbagai objek wisata yang ditawarkan mulai dari gunung, pandai, gua hingga air terjun yang hampir terdapat pada setiap kabupaten/kota di Jawa Timur. Jawa Timur juga dikenal sebagai pusat industri dan keuangan kawasan Timur Indonesia.

Pertumbuhan ekonomi Indonesia memiliki sifat ketergantungan antar negara yang dipengaruhi oleh hubungan diplomatic atau arus globalisasi. Pada saat suatu negara mengalami krisis, maka negara yang lain pun akan merasakan dampak dari krisis tersebut (Estuningtyas, 2018). Pada akhir 2019 dunia sedang diguncang dengan munculnya sebuah virus yang berasal dari Kota Wuhan, China yaitu virus Covid-19 (Corona). Virus ini menunjukkan penyebaran yang sangat signifikan cepat dan telah banyak kematian yang disebabkan dari virus ini sehingga pada tanggal 30 Januari 2020 WHO menetapkan virus corona ini sebagai Kedaruratan Kesehatan Masyarakat 
yang Meresahkan Masyarakat (Public Health Emergency of International Concern) hingga pada tanggal 11 Maret 2020, WHO mengumumkan bahwa wabah yang sedang terjadi saat ini sebagai Pandemi Global.

Adanya pandemi covid-19 ini berdampak pada perekonomian global. China sebagai pemegang kegiatan ekspor terbesar di dunia yang mana virus covid-19 pertamakali menjangkit di China, sehingga membawa kegiatan dagang China kearah yang negatif. Apabila terjadi koreksi negatif atas produksi di China maka dunia akan mengalami gangguan supply chain, pada akhirnya dapat menurunkan proses produksi dunia yang bahan bakunya di impor dari China (Perencanaan et al., 2020). Negara Indonesia sendiri sangat membutuhkan bahan baku dari China untuk melakukan proses produksi khususnya bahan baku sparepart elektronik, furnitur, plastik, tekstil dan komputer.

Gambar 1. Laju Pertumbuhan PDRB Provinsi Jawa Timur

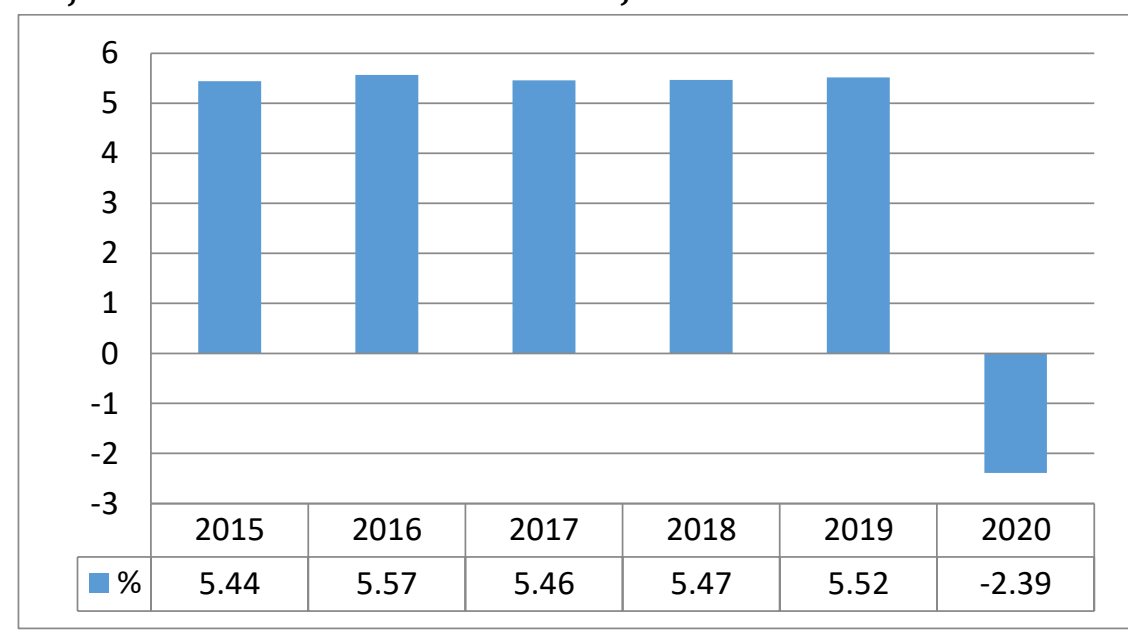

Sumber: BPS Jawa Timur (2020)

Pada gambar diatas terlihat dampak adanya pandemi Covid-19 yang dimuali awal tahun 2020 dirasakan pada laju pertumbuhan ekonomi yang menurun secara drastis hingga mencapai minus 2,39 persen. Sehingga pasti terjadi pergeseran struktur perekonomian dalam PDRB sebelum adanya pandemi dan saat terjadi adanya pandemi covid-19 dan perlu dianalisis lebih jauh untuk mengetahui sektor - sektor yang potensial untuk dikembangkan agar dapat mendongkrak sektor lain.

Schumpeter dan Hicks dalam (Jhingan, 2014) bahwa terdapat perbedaan dalam istilah pembangunan ekonomi dan pertumbuhan ekonomi. Pembangunan ekonomi terjadi perubahan secara spontan dan terputus - putus dalam keadaan stasioner yang senantiasa mengubah dan mengganti situasi keseimbangan yang ada sebelumnya. Sedangkan pertumbuhan ekonomi merupakan perubahan jangka panjang secara perlahan dan stabil yang terjadi melalui kenaikan tabungan dan populasi. 
Pertumbuhan ekonomi merupakan proses kenaikan output perkapita dalam jangka panjang. Intinya terdapat pada tiga aspek, yaitu: proses, output perkapita dan jangka panjang (Fatmawati, 2015). Pertumbuhan ekonomi merupakan suatu proses, bukanlah gambaran ekonomi pada suatu saat, sehingga dapat dilihat aspek dinamis dari suatu perekonomian (berkembang atau berubah dari waktu ke waktu). Jika seluruh balas jasa riil terhadap penggunaan faktor produksi pada tahun tertentu lebih besar dari pada tahun sebelumnya, maka perekonomian dianggap mengalami pertumbuhan. Dengan kata lain perekonomian mengalami pertumbuhan jika pendapatan riil masyarakt pada tahun tertentu lebih besar dari pendapatan tahun sebelumnya.

Pembangunan Ekonomi dapat diartikan sebagai kegiatan yang dilakukan oleh suatu wilayah untuk mengembangkan kegiatan ekonomi serta taraf hidup masyarakatnya. Tingkat taraf hidup suatu masyarakat dapat diukur melalui tinggi rendahnya pendapatan riil per kapita. Sehingga pembangunan ekonomi dapat diartikan pula sebagai proses yang bertujuan untuk menaikan Produk Domestik Bruto (PDB) suatu wilayah melebihi tingkat pertumbuhan penduduk (Purnamasari, 1992).

Pembangunan merupakan bagian yang tidak dapat terpisahkan dari pertumbuhan, dalam artian bahwa dengan adanya pembangunan dapat menyebabkan terjadinya pertumbuhan, yang mana pertumbuhan dalam hal ini dapat berupa pengembangan maupun perluasan dari aktivitas yang dilakukanoleh suatu komunitas masyarakat, dan pertumbuhan akan terjadi akibat adanya pembangunan (Basuki \& Prawoto, 2015).

Potensi sektoral ekonomi daerah merupakan suatu kondisi tertentu dimana perekonomian daerah dipetakan berdasarkan sektor usaha dalam PDRB dengan keunggulan-keuggulan tertentu pada setiap sektor usaha (Primadhana \& Wahed, 2020). Masalah utama dalam pembangunan daerah yaitu terletak pada penekanan kebijakan-kebijakan pembangunan yang didasarkan pada kekhasan daerah yang bersangkutan dengan menggunakan potensi sumberdaya manusia, kelembagaan, dan sumberdaya fisik secara local.

Menurut Rachbini dalam jurnal (Hajeri et al., 2015) ada empat syarat agar suatu sektor tertentu menjadi sektor prioritas, yakni 1) sektor tersebut harus menghasilkan produk yang mempunyai permintaan yang cukup besar; 2) karena ada perubahan teknologi yang teradopsi secara kreatif; 3) harus terjadi peningkatan investasi kembali dari hasil-hasil produksi sektor yang menjadi prioritas tersebut; dan 4) sektor tersebut harus berkembang. Pengukuran potensi daerah dilakukan dengan menggunakan sejumlah alat analisis. Alat analisis tersebut meliputi:1) Locationt Quatient (LQ), 2) Shift-Share (S-S), dan 3) Tipologi Klassen.

Produk Domestik Bruto atau Produk Regional Bruto merupakan salah satu indikator ekonomi makro yang digunakan untuk mengevaluasi hasil - hasil pembangunan di suatu Negara ataupun Daerah. Produk Domestik Bruto dalam taraf nasional dan Produk Domestik Regional Bruto (PDRB) dalam rtaraf regional (provinsi) 
menjelaskan tentang kemampuan suatu daerah dalam menciptakan nilai tambah di suatu waktu tertentu. (BPS Provinsi Jawa Timur, 2021).

PDRB tahun dasar 2010 telah mengacu pada Sistem Neraca Nasional (SNN) 2008, dimana SNN 2008 merupakan rekomendasi internasional mengenai penyusunan ukuran aktivitas ekonomi yang sesuai dengan standar neraca baku dan didasarkan pada prinsip - prinsip ekonomi (Widjajanto \& Agus, 2020). Perubahan klasifikasi PDB menurut lapangan usaha sejak tahun 2010 terbagi menjadi 17 sektor, yaitu Pertanian, Kehutanan, dan Perikanan; Pertambangan dan Penggalian; Industri Pengolahan; Pengadaan Listrik dan Gas; Pengadaan Air, Pengelolaan Sampah, Limbah, dan Daur Ulang, Konstruksi; Perdagangan Besar dan Eceran; Reparasi Mobil dan Sepedah Motor; Transportasi dan Pergudangan; Penyediaan Akomodasi dan Makan Minum; Informasi dan Komunikasi; Jasa Keuangan dan Asuransi; Real Estate; Jasa Perusahaan; Administrasi Pemerintahan, Pertahanan, dan Jaminan Sosial Wajib; Jasa Pendidikan; Jasa Kesehatan dan Kegiatan Sosial; Jasa Lainnya .

\section{METODE PENELITIAN}

Lokasi dalam penelitian ini adalah Provinsi Jawa Timur dengan ruang lingkup waktu enam tahun yaitu 2015 hingga 2020. Sumber data yang digunakan adalah data sekunder yang diperoleh dari Badan Pusat Statistika (BPS) Nasional \& Badan Pusat Statistika (BPS) Provinsi Jawa Timur. Teknik pengumpulan data yang digunakan adalah dokumentasi dengan cara melakukan penganalisaan dan pengelolaan terhadap data yang berhubungan dengan variabel yang diteliti . Penelitian ini berfokus pada pergeseran pangsa sektor-sektor ekonomi dan untuk mengetahui sektor unggulan yang memiliki potensi untuk dikembangkan. Dalam penelitian ini teknik analisis yang digunakan adalah sebagai berikut :

\section{Analisis Location Quotient (LQ)}

Location Quotient (LQ) merupakan perbandingan tentang besaran sektor/industri disuatu daerah terhadap besarnya peranan sektor/industri tersebut secara nasional (DRS. ROBINSON TARIGAN, 2014). Teknik ini meyajikan perbandingan antara kemampuan suatu sektor di daerah yang sedang diteliti dengan kemampuan sektor yang sama pada daerah yang lebih luas. Kontribusi sektor ekonomi di Provinsi Jawa Timur diformulasikan dengan model LQ sebagai berikut:

$$
\mathrm{LQ}=\frac{y i / y}{Y i / Y}
$$

Terdapat tiga kemungkinan setelah dilakukannya perhitungan dengan menggunakan rumus diatas, yaitu :

1. Apabila nilai LQ $>1$. Artinya sektor tersebut dikategorikan sebagai sektor basis atau menjadi sektor pertumbuhan. Komoditas di sektor i tersebut memiliki keunggulan komperatif yang hasilnya tidak hanya dapat memenuhi kebutuhan di wilayahnya, melainkan dapat pula diekspor ke luar wilayah.

2. Nilai $L Q=1$. Artinya sektor tersebut hanya cukup memenuhi kebutuhan di 
wilayahnya saja. Tingkat spesialisasi wilayah yang diteliti sama dengan wilayah pembanding.

3. Nilai $L Q<1$. Artinya sektor tersebut dikategorikan sebagai sektor non basis. Sektor yang ada kurang prospektif untuk dikembangkan sehingga memerlukan impor dari wilayah luar.

\section{Analisis Shift-Share}

Merupakan analisis yang digunakan untuk mengetahui peranan suatu sektor maupun pergeseran suatu sektor di daerah terhadap sektor yang sama dalam perekonomian nasional. Terdapat tiga informasi dasar yang akan diperoleh dari analisis shift-share yang saling berhubungan satu sama lain, yaitu :

1. Potensial Regional

Melalui analisis ini dapat diketahui sektor yang mendorong maupun menghambat pertumbuhan ekonomi di wilayah Jawa Timur. Dapat dinyatakan dengan rumus sebagai berikut:

$$
P R_{i j}=\left\{Q_{i j}^{0} \frac{Y_{t}}{Y_{0}}-1\right\}
$$

Bila $P R<Q_{i j}$ maka pertumbuhan sektor i di Provinsi Jawa Timur akan mendorong pertumbuhan sektor yang sama di Nasional.

Bila $P R>Q_{i j}$ maka pertumbuhan sektor i di Provinsi Jawa Timur akan menghambat pertumbuhan yang sama di Nasional.

2. Proportional Shift (PS)

Dikenal sebagai komponen struktural atau industrial mix yang menunjukkan perubahan kinerja dari suatu sektor ekonomi (lapangan usaha) di Provinsi Jawa Timur terhadap sektor yang sama di Nasional. Perubahan yang diukur yaitu relative, tumbuh lebih cepat atau lebih lambat. Dapat dinyatakan dengan rumus sebagai berikut:

$$
P S_{i j}=Q_{i j}^{0}\left\{\frac{Q_{i}^{t}}{Q_{i}^{0}}-\frac{Y_{t}}{Y_{0}}\right\}
$$

Bila PS $>0$, Maka sektor tersebut tumbuh lebih cepat dari sektor yang sama di tingkat Nasional.

Bila PS $<0$, Maka sektor tersebut tumbuh lebih lambat dari sektor yang sama di tingkat Nasional.

3. Differential Shift

Disebut juga dengan keunggulan kompetitif. Melalui analisis ini dapat diketahui seberapa jauh kemampuan daya saing industri di Provinsi Jawa Timur dengan perekonomian Nasional yang dijadikan referensi. Dapat dinyatakan dengan rumus sebagai berikut:

$$
D S_{i j}=Q_{i j}^{0}\left\{\frac{Q_{i j}^{t}}{Q_{i j}^{0}}-\frac{Q_{i}^{t}}{Q_{i}^{0}}\right\}
$$

Bila DS $>0$, maka sektor tersebut memiliki pertumbuhan yang lebih cepat dari wilayah yang lain (lokasional) / sektor tersebut memiliki daya 
saing kuat. Bila DS $<0$, maka sektor tersebut memiliki pertumbuhan yang lebih lambat dari wilayah yang lain (lokasional) / sektor tersebut memiliki daya saing lemah

\section{Analisis Kuadran}

Merupakan salah satu alat analisis ekonomi daerah yang dapat digunakan untuk menentukan klasifikasi sektor ekonomi dengan menjumlahkan komponen proportional shift (PS) dan komponen differential shift (Ds), tujuannya adalah untuk menentukan posisi sektor ekonomi di suatu wilayah berdasarkan dua karakteristik yang dimiliki yaitu pertumbuhan dan kontribusi sektor ekonomi dalam suatu wilayah (Yasa, 2011). Penjumlahan dari kedua komponen tersebut disebut juga dengan pergeseran bersih (net shift) yang dinyatakan sebagai berikut:

$$
\text { Ns }=\text { Ps }+ \text { Ds }
$$

Bila Ns $>0$, maka pertumbuhan sektor i di Provinsi Jawa Timur termasuk ke dalam kelompok progresif (maju). Bila Ns $<0$, maka pertumbuhan sektor i di Provinsi Jawa Timur termasuk ke dalam kelompok lamban.

Hasil analisis dari masing-masing sektor ekonomi dapat klasifikasikan ke dalam 4 bagian/kuadran, yaitu :

a. Kuadran I. Jika nilai Ps maupun Ds suatu sektor ekonomi positif, artinya sektor didalam kuadran ini memiliki pertumbuhan yang cepat dan daya saing yang kuat.

b. Kuadran II. Jika nilai Ps negates namun Ds positif, artinya sektor didalam kuadran ini memiliki pertumbuhan yang lambat namun memiliki daya saing yang kuat.

c. Kuadran III. Jika nilai Ps potif namun Ds negatif, artinya sektor dalam kuadran ini memiliki pertumbuhan yang cepat namun memiliki daya saing yang lemah.

d. Kuadran IV. Jika nilai Ps dan Ds negatif, artinya sektor didalam kuadran ini memiliki pertumbuhan yang lamban dan daya saing yang lemah.

\section{HASIL DAN PEMBAHASAN}

Fokus analisis dilakukan melalui data Produk Domestik Regional Bruto (PDRB) Provinsi Jawa Timur Atas Dasar Harga Konstan Menurut Lapangan Usaha. Adanya pandemi mengakibatkan adanya perubahan kehidupan ekonomi masyarakat. Berikut adalah perbandingan hasil perhitungan Location Quotient (LQ) sebelum dan saat terjadinya Pandemi Covid-19: 


\begin{tabular}{lcccc}
\hline \multirow{2}{*}{\multicolumn{1}{c}{ Kategori Sektor }} & \multicolumn{2}{c}{$\begin{array}{c}\text { Sebelum Pandemi } \\
\text { Covid-19 }\end{array}$} & \multicolumn{2}{c}{$\begin{array}{c}\text { Saat Pandemi } \\
\text { Covid-19 }\end{array}$} \\
\cline { 2 - 5 } & LQ & Ket & LQ & Ket \\
\hline Pertanian, Kehutanan dan Perikanan & 0.80 & NB & 0.78 & NB \\
\hline Pertambangan dan Penggalian & 0.64 & NB & 0.65 & NB \\
\hline Industri Pengolahan & 1.35 & $\mathrm{~B}$ & 1.42 & $\mathrm{~B}$ \\
\hline Pengadaan Listrik dan Gas & 0.28 & $\mathrm{NB}$ & 0.26 & $\mathrm{NB}$ \\
\hline Pengadaan Air, Pengelolaan Sampah, Limbah dan Daur Ulang & 1.15 & $\mathrm{~B}$ & 1.13 & $\mathrm{~B}$ \\
\hline Konstruksi & 0.89 & $\mathrm{NB}$ & 0.89 & $\mathrm{NB}$ \\
\hline Perdagangan Besar dan Eceran & 1.34 & $\mathrm{~B}$ & 1.34 & $\mathrm{~B}$ \\
\hline Transportasi dan Pergudangan & 0.68 & $\mathrm{NB}$ & 0.70 & $\mathrm{NB}$ \\
\hline Penyediaan Akomodasi dan Makan Minum & 1.70 & $\mathrm{~B}$ & 1.79 & $\mathrm{~B}$ \\
\hline Informasi dan Komunikasi & 1.09 & $\mathrm{~B}$ & 1.05 & $\mathrm{~B}$ \\
\hline Jasa Keuangan dan Asuransi & 0.62 & $\mathrm{NB}$ & 0.58 & $\mathrm{NB}$ \\
\hline Real Estate & 0.57 & $\mathrm{NB}$ & 0.59 & $\mathrm{NB}$ \\
\hline Jasa Perusahaan & 0.43 & $\mathrm{NB}$ & 0.40 & $\mathrm{NB}$ \\
\hline Administrasi Pemerintahan, Pertahanan dan Jaminan Sosial & 0.63 & $\mathrm{NB}$ & 0.61 & $\mathrm{NB}$ \\
\hline Jasa Pendidikan & 0.82 & $\mathrm{NB}$ & 0.84 & $\mathrm{NB}$ \\
\hline Jasa Kesehatan dan Kegiatan Sosial & 0.58 & $\mathrm{NB}$ & 0.55 & $\mathrm{NB}$ \\
\hline Jasa Lainnya & 0.80 & $\mathrm{NB}$ & 0.67 & $\mathrm{NB}$ \\
\hline Sumber: Data PDRB Provinsi Jawa Timur ADHK
\end{tabular}

Sumber: Data PDRB Provinsi Jawa Timur ADHK (diolah)

Dari perhitungan LQ diketahui bahwa Provinsi Jawa Timur memiliki 5 sektor basis lain sektor Industri Pengolahan; Pengadaan Air, Pengelolaan Sampah, Limbah dan Daur Ulang; Perdagangan Besar dan Eceran; Penyediaan Akomodasi dan Makan Minum; Informasi dan Komunikasi. Adanya pandemi Covid-19 membuat PDRB Jawa Timur mengalami perlambatan yang terjadi hampir pada seluruh sektor. Pemerintah secara sigap melakukan berbagai cara untuk memulihkan dan meningkatkan ekonomi salah satunya yaitu dengan melakukan langkah refocusing dan realokasi.

Tabel 2. Hasil Analisis Shift Share Potentioal Regional (PR) Provinsi Jawa Timur Sebelum Pandemi

\begin{tabular}{lrrcrcc}
\hline \multirow{2}{*}{\multicolumn{1}{c}{ Kategori Sektor }} & \multicolumn{2}{c}{ Sebelum Pandemi Covid-19 } & \multicolumn{3}{c}{ Saat Pandemi Covid-19 } \\
\cline { 2 - 8 } & \multicolumn{1}{c}{ PR } & \multicolumn{1}{c}{$\Delta$ Qij } & Score & \multicolumn{1}{c}{ PR } & \multicolumn{1}{c}{$\Delta$ Qij } & Score \\
\hline Pertanian, Kehutanan dan Perikanan & 7659.70 & 1990.84 & 0 & -2623.09 & $1,565.49$ & 1 \\
\hline Pertambangan dan Penggalian & 3478.98 & 4585.06 & 1 & -1326.08 & $-3,500.87$ & 0 \\
\hline Industri Pengolahan & 19706.53 & 25311.79 & 1 & -7895.56 & $-10,280.82$ & 0 \\
\hline Pengadaan Listrik dan Gas & 210.65 & 3.19 & 0 & -72.19 & -109.14 & 0 \\
\hline $\begin{array}{l}\text { Pengadaan Air, Pengelolaan Sampah, } \\
\text { Limbah dan Daur Ulang }\end{array}$ & 65.13 & 70.53 & 1 & -25.11 & 79.80 & 1 \\
\hline Konstruksi & 6107.06 & 7438.28 & 1 & -2432.40 & $-5,037.15$ & 0 \\
\hline Perdagangan Besar dan Eceran & 12274.03 & 15443.02 & 1 & -4865.78 & $-17,640.51$ & 0 \\
\hline Transportasi dan Pergudangan & 1967.92 & 2401.92 & 1 & -767.14 & $-5,411.14$ & 0 \\
\hline
\end{tabular}


Jambura Economic Education Journal

Nurul Assidikiyah, Marseto, Sishadiyati

Analisis Potensi Pertumbuhan Ekonomi...
Volume 3 No 2 July 2021

hlm. $102-115$

\begin{tabular}{|c|c|c|c|c|c|c|}
\hline $\begin{array}{l}\text { Penyediaan Akomodasi dan Makan } \\
\text { Minum }\end{array}$ & 3509.73 & 5772.32 & 1 & -1450.83 & $-8,130.77$ & 0 \\
\hline Informasi dan Komunikasi & 3775.40 & 5583.11 & 1 & -1536.31 & $9,541.91$ & 1 \\
\hline Jasa Keuangan dan Asuransi & 1732.43 & 1794.99 & 1 & -654.82 & 74.73 & 1 \\
\hline Real Estate & 1150.58 & 1288.64 & 1 & -450.14 & $1,124.19$ & 1 \\
\hline Jasa Perusahaan & 520.14 & 662.60 & 1 & -207.77 & -948.00 & 0 \\
\hline $\begin{array}{l}\text { Administrasi Pemerintahan, } \\
\text { Pertahanan dan Jaminan Sosial }\end{array}$ & 1484.51 & 1250.95 & 0 & -553.69 & -135.83 & 1 \\
\hline Jasa Pendidikan & 1765.83 & 2170.81 & 1 & -696.68 & $1,741.04$ & 1 \\
\hline Jasa Kesehatan dan Kegiatan Sosial & 441.16 & 613.00 & 1 & -178.49 & 981.66 & 1 \\
\hline Jasa Lainnya & 962.27 & 1035.71 & 1 & -374.34 & $-3,263.05$ & 0 \\
\hline
\end{tabular}

Sumber: Data PDRB Provinsi Jawa Timur ADHK (diolah)

Berdasarkan hasil analisis Shift-Share Potentional Regional (PR) pada tabel 2 menunjukkan bahwa terdapat perubahan sektor yang berpengaruh dalam pembentukan PDB nasional. Sebelum adanya pandemi Covid-19 sektor-sektor yang cenderung mendorong pertumbuhan Nasional yaitu sektor Pertambangan dan Penggalian, Industri Pengolahan, Pengadaan air, pengelolaan sampah, limbah dan daur ulang, Konstruksi, Perdagangan Besar dan Eceran, Transportasi dan Pergudangan, Penyediaan akomodasi dan makan minum, Informasi dan Komunikasi, Jasa Keuangan dan Asuransi, Real Estate, Jasa Perusahaan, Jasa Pendidikan, Jasa Kesehatan dan Kegiatan Sosial, Jasa Lainnya. Sedangkan saat terjadi pandemi Covid-19 sektor-sektor yang mendorong pertumbuhan Nasional yaitu sektor Pertanian, Kehutanan dan Perikanan, Pengadaan air, pengelolaan sampah, limbah dan daur ulang, Informasi dan Komunikasi, Jasa Keuangan dan Asuransi, Real Estate, Administrasi Pemerintahan, Pertahanan dan Jaminan Sosial, Jasa Pendidikan, Jasa Kesehatan dan Kegiatan Sosial.

Tabel 3. Hasil Analisis Shift Share Proportional Shift (PS) dan differential shift (Ds) Provinsi Jawa Timur Sebelum Pandemi

\begin{tabular}{|c|c|c|c|c|c|c|c|c|}
\hline \multirow[t]{2}{*}{ Kategori Sektor } & \multicolumn{2}{|c|}{$\begin{array}{l}\text { Sebelum } \\
\text { Pandemi } \\
\text { Covid-19 }\end{array}$} & \multicolumn{2}{|c|}{$\begin{array}{c}\text { Saat Terjadi } \\
\text { Pandemi } \\
\text { Covid-19 }\end{array}$} & \multicolumn{2}{|c|}{$\begin{array}{l}\text { Sebelum } \\
\text { Pnademi } \\
\text { Covid-19 }\end{array}$} & \multicolumn{2}{|c|}{$\begin{array}{c}\text { Saat Terjadi } \\
\text { Pandemi Covid- } \\
19\end{array}$} \\
\hline & Ps & $\begin{array}{c}\text { Scor } \\
\text { e }\end{array}$ & Ps & $\begin{array}{c}\text { Scor } \\
\mathrm{e}\end{array}$ & Ds & $\begin{array}{c}\text { Scor } \\
\mathrm{e}\end{array}$ & Ds & $\begin{array}{c}\text { Scor } \\
\mathrm{e}\end{array}$ \\
\hline Pertanian, Kehutanan dan Perikanan & 1832,65 & 0 & $\begin{array}{r}5527 \\
21 \\
\end{array}$ & 1 & 4859,39 & 0 & - & 0 \\
\hline Pertambangan dan Penggalian & 2701,36 & 0 & $-308,81$ & 0 & 3554,97 & 1 & $-1865,975$ & 0 \\
\hline Industri Pengolahan & 2885,12 & 0 & 6730,50 & 0 & 8735,56 & 1 & 4345,238 & 1 \\
\hline Pengadaan Listrik dan Gas & $-31,36$ & 0 & $-34,65$ & 0 & $-159,25$ & 0 & $-2,302$ & 0 \\
\hline $\begin{array}{l}\text { Pengadaan Air, Pengelolaan Sampah, } \\
\text { Limbah dan Daur Ulang }\end{array}$ & 5,57 & 1 & 103,42 & 1 & $-1,63$ & 0 & 1,493 & 1 \\
\hline Konstruksi & 1519,20 & 1 & 2571,72 & 0 & 350,31 & 1 & $-33,033$ & 0 \\
\hline
\end{tabular}




\begin{tabular}{|c|c|c|c|c|c|c|c|c|}
\hline Perdagangan Besar dan Eceran & $-777,34$ & 0 & $\begin{array}{r}- \\
6568,85\end{array}$ & 0 & 4064,40 & 1 & $-6205,882$ & 0 \\
\hline Transportasi dan Pergudangan & 1059,83 & 1 & $6524,70^{-}$ & 0 & $-721,97$ & 0 & 1880,708 & 1 \\
\hline $\begin{array}{l}\text { Penyediaan Akomodasi dan Makan } \\
\text { Minum }\end{array}$ & 541,19 & 1 & $\begin{array}{r}- \\
7916,37\end{array}$ & 0 & 1777,16 & 1 & 1236,424 & 1 \\
\hline Informasi dan Komunikasi & 3202,98 & 1 & $\begin{array}{r}11809,9 \\
9\end{array}$ & 1 & $-1300,01$ & 0 & $-731,766$ & 0 \\
\hline Jasa Keuangan dan Asuransi & 534,31 & 1 & 1998,41 & 1 & $-678,21$ & 0 & $-1268,857$ & 0 \\
\hline Real Estate & $-103,09$ & 0 & 1110,53 & 1 & 241,83 & 1 & 463,791 & 1 \\
\hline Jasa Perusahaan & 440,99 & 1 & $-506,88$ & 0 & $-288,98$ & 0 & $-233,343$ & 0 \\
\hline $\begin{array}{l}\text { Administrasi Pemerintahan, } \\
\text { Pertahanan dan Jaminan Sosial }\end{array}$ & $-181,41$ & 0 & 544,80 & 1 & $-173,29$ & 0 & $-126,939$ & 0 \\
\hline Jasa Pendidikan & 13,77 & 1 & 1854,00 & 1 & 317,83 & 1 & 583,720 & 1 \\
\hline Jasa Kesehatan dan Kegiatan Sosial & 212,01 & 1 & 1486,28 & 1 & $-39,07$ & 0 & $-326,126$ & 0 \\
\hline Jasa Lainnya & 892,21 & 1 & $-595,09$ & 0 & $-824,43$ & 0 & $-2293,627$ & 0 \\
\hline
\end{tabular}

Sumber: Data PDRB Provinsi Jawa Timur ADHK (diolah)

Pertumbuhan proportional shift (Ps) yang bernilai positif (score 1) menunjukkan bahwa perekonomian di Provinsi Jawa Timur memiliki pertumbuhan yang relative cepat, sebaliknya jika bernilai negatif (score 0) menunjukkan bahwa perekonomian di Provinsi Jawa Timur memiliki pertumbuhan yang relative lambat. Berdasarkan tabel 3 sektor yang memiliki pertumbuhan relative cepat pada saat sebelum adanya pandemi covid-19 yaitu sektor Pengadaan air, Pengelolahan Sampah, Limbah dan Daur Ulang; Konstruksi, Transportasi dan Pergudangan; Penyediaan akomodasi dan Makan Minum; Informasi dan Komunikasi; Jasa Keuangan dan Asuransi; Jasa Perusahaan; Jasa Pendidikan; Jasa Kesehatan dan Kegiatan Sosial dan Jasa Lainnya. Sedangkan terdapat perubahan pada saat terjadi pandemi Covid-19, sektor yang masih dapat bertahan dan memiliki pertumbuhan yang cepat pada saat pandemi antara lain yaitu sektor Pertanian, Kehutanan dan Perikanan; Pengadaan Air, Pengelolaan Sampah, Limbah dan Daur Ulang; Informasi dan Komunikasi; Jasa Keuangan dan Asuransi; Real Estate; Administrasi pemerintahan, pertahanan dan Jaminan sosial; Jasa Pendidikan; dan Jasa Kesehatan dan Kegiatan Sosial.

Hasil dari different shift (Ds) yang bernilai positif (score 1) artinya sektor tersebut mempunyai keuntungan lokasional. Dan sebaliknya jika mempunyai nilai negatif (score 0) artinya sektor tersebut tidak memiliki keuntungan lokasional. Sektor yang mempunyai keuntungan lokasional sebelum adanya pandemi covid-19 yaitu sektor Industri pengolahan; Perdagangan besar dan eceran; Konstruksi; Penyedia Akomodasi dan Makan Minum; Real Estate dan Jasa Pendidikan. Sedangakan sektor yang mempunyai keuntungan lokasional dimasa pandemi Covid-19 yaitu sektor Industri Pengolahan; Pengadaan Air, Pengelolaan Sampah, Limbah dan Daur Ulang; Transportasi dan Pergudangan; Penyediaan Akomodasi dan Makan Minum; Real Estate; Jasa Pendidikan. Nilai pergeseran bersih (net shift) diperoleh dari hasil penjumlahan antara komponen Ps dan komponen Ds setiap sektor ekonomi. Sektor 
yang memiliki nilai net shift positif (Ns>0) artinya sektor tersebut masuk dalam kelompok progresif, sebaliknya jika bernilai negatif $(\mathrm{Ns}<0)$ maka termasuk dalam kelompok yang pertumbuhannya lamban.

Tabel 4. Hasil Analisis Net Shift (Ns) Provinsi Jawa Timur Sebelum dan saat terjadi Pandemi

\begin{tabular}{|c|c|c|c|c|}
\hline \multirow{2}{*}{ Kategori Sektor } & \multicolumn{2}{|c|}{$\begin{array}{l}\text { Sebelum Pandemi Covid- } \\
19\end{array}$} & \multicolumn{2}{|c|}{ Saat Pandemi Covid-19 } \\
\hline & Ns & Ket & Ns & Ket \\
\hline Pertanian, Kehutanan dan Perikanan & $-6692,03$ & Lamban & 4188,58 & Progresif \\
\hline Pertambangan dan Penggalian & 853,61 & Progresif & $-2174,79$ & Lamban \\
\hline Industri Pengolahan & 5850,44 & Progresif & $-2385,26$ & Lamban \\
\hline Pengadaan Listrik dan Gas & $-190,61$ & Lamban & $-36,95$ & Lamban \\
\hline $\begin{array}{l}\text { Pengadaan Air, Pengelolaan Sampah, Limbah dan } \\
\text { Daur Ulang }\end{array}$ & 3,94 & Progresif & 104,91 & Progresif \\
\hline Konstruksi & 1869,51 & Progresif & $-2604,75$ & Lamban \\
\hline Perdagangan Besar dan Eceran & 3287,06 & Progresif & $-12774,73$ & Lamban \\
\hline Transportasi dan Pergudangan & 337,86 & Progresif & $-4644,00$ & Lamban \\
\hline Penyediaan Akomodasi dan Makan Minum & 2318,35 & Progresif & $-6679,94$ & Lamban \\
\hline Informasi dan Komunikasi & 1902,97 & Progresif & 11078,22 & Progresif \\
\hline Jasa Keuangan dan Asuransi & $-143,90$ & Lamban & 729,55 & Progresif \\
\hline Real Estate & 138,75 & Progresif & 1574,33 & Progresif \\
\hline Jasa Perusahaan & 152,01 & Progresif & $-740,23$ & Lamban \\
\hline $\begin{array}{l}\text { Administrasi Pemerintahan, Pertahanan dan } \\
\text { Jaminan Sosial }\end{array}$ & $-354,69$ & Lamban & 417,86 & Progresif \\
\hline Jasa Pendidikan & 331,60 & Progresif & 2437,72 & Progresif \\
\hline Jasa Kesehatan dan Kegiatan Sosial & 172,94 & Progresif & 1160,15 & Progresif \\
\hline Jasa Lainnya & 67,78 & Progresif & $-2888,71$ & Lamban \\
\hline
\end{tabular}

Sumber: Data diolah

Berdasarkan hasil perhitungan net shift dapat diketahui bahwa hampir seluruh sektor terkena dampak dari adanya pandemi Covid-19. Beberapa sektor yang mengalami pertumbuhan yaitu sektor Pertanian, kehutanan dan perikanan karena permintaan di sektor pangan yang tetap tinggi di masa pandemi. Sektor informasi dan komunikasi berperan sebagai enabler (fasilitator) dalam mendorong keberlangsungan kegiatan produktif di tengah pandemi. Sektor pengadaan air, pengelolaan sampah, limbah dan daur ulang; Jasa Pendidikan; Jasa kesehatan dan kegiatan sosial masuk dalam sektor yang mendapat realokasi dan refocusing sehingga sektor tersebut mampu bertahan di masa pandemic.

Dengan melihat nilai Ps dan Ds pada tabel 3, maka suatu sektor ekonomi dapat dikelompokkan menjadi 4 (empat) kuadran yaitu kuadran I, kuadran II, kuadran III dan kuadran IV. Dalam bentuk grafik, posisi masing masing sektor ekonomi sebelum adanya pandemi Covid-19 dan saat terjadi pandemi Covid-19 dalam kuadran terlihat sebagai berikut : 
Tabel 5. Analisis Kuadran Sektor Ekonomi Sebelum dan Saat Terjadinya Pandemi Covid-19

\begin{tabular}{|c|c|c|}
\hline $\begin{array}{l}\text { Analisis } \\
\text { Kuadran }\end{array}$ & Sebelum Pandemi Covid-19 & Saat Pandemi Covid-19 \\
\hline $\begin{array}{l}\text { Kuadran I } \\
\text { (Cepat,Kuat) }\end{array}$ & $\begin{array}{l}\text { Konstruksi } \\
\text { Penyedia akomodasi dan makan minum } \\
\text { Jasa Pendidikan }\end{array}$ & $\begin{array}{l}\text { Pengadaan Air, Pengelolaan Sampah, } \\
\text { Limbah dan Daur Ulang } \\
\text { Real Estate } \\
\text { Jasa Pendidikan }\end{array}$ \\
\hline $\begin{array}{l}\text { Kuadran II } \\
\text { (Lambat, Kuat) }\end{array}$ & $\begin{array}{l}\text { Pertambangan \& Penggalian } \\
\text { Industri Pengolahan } \\
\text { Konstrruksi } \\
\text { Perdagangan Besar \& Eceran } \\
\text { Transportasi \& Pergudangan } \\
\text { Real Estate }\end{array}$ & $\begin{array}{l}\text { Industri Pengolahan } \\
\text { Transportasi dan Pergudangan } \\
\text { Penyedia Akomodasi \& Makan Minum }\end{array}$ \\
\hline $\begin{array}{l}\text { Kuadran III } \\
\text { (Cepat, Lemah) }\end{array}$ & $\begin{array}{l}\text { Pengadaan Air, Pengelolaan Sampah, } \\
\text { Limbah \& Daur Ulang } \\
\text { Informasi \& Komunikasi } \\
\text { Jasa Keuangan dan Asuransi } \\
\text { Jasa Perusahaan } \\
\text { Jasa Kesehatan \& Kegiatan Sosial } \\
\text { Jasa Lainnya }\end{array}$ & $\begin{array}{l}\text { Pertanian, Kehutanan \& Perikanan } \\
\text { Informasi \& Komunikasi } \\
\text { Jasa Keuangan \& Asuransi } \\
\text { Adm. Pemerintahan, Pertahanan dan } \\
\text { Jaminan Sosial } \\
\text { Jasa Kesehatan \& Kegiatan Sosial }\end{array}$ \\
\hline $\begin{array}{l}\text { Kuadran IV } \\
\text { (Lambat, } \\
\text { Lemah) }\end{array}$ & $\begin{array}{l}\text { Pertanian, Kehutana \& Perikanan } \\
\text { Pengadaan Listrik \& Gas } \\
\text { Adm. Pemerintahan, Pertahanan \& Jaminan } \\
\text { Sosial }\end{array}$ & $\begin{array}{l}\text { Pertambangan\&Penggalian } \\
\text { Pengadaan Listrik \& Gas } \\
\text { Konstruksi } \\
\text { Perdagangan Besar\&Eceran } \\
\text { Jasa Perusahaan } \\
\text { Jasa Lainnya }\end{array}$ \\
\hline
\end{tabular}

Sumber: Dokumen Penulis

\section{KESIMPULAN}

Hasil dari analisis LQ sebelum dan saat terjadinya pandemic Covid-19 terlihat bahwa terdapat beberapa sektor mengalami kemunduran, namun tidak merubah kategori basis dan non basis sektor-sektor di Provinsi jawa Timur. Hal tersebut menunjukkan bahwa pemerintah Provinsi Jawa Timur mampu dengan sigap mengendalikan ketidakstabilan ekonomi yang merupakan dampak dari adanya pandemic Covid-19. Sektor basis di Jawa Timur antara lain sektor Industri Pengolahan; Pengadaan Air, Pengelolaan Sampah, Limbah dan Daur Ulang; Perdagangan Besar dan Eceran; Penyediaan Akomodasi dan Makan Minum; Informasi dan Komunikasi.

Analisis Shift-share dan analisis Kuadran menunjukkan perbedaan kondisi ekonomi yang terjadi pada sebelum dan saat terjadinya pandemic Covid-19. Terdapat perlambatan hampir pada seluruh sektor ekonomi di Provinsi Jawa Timur. Perlambatan kinerja disebabkan oleh pandemi covid-19 dan pembatasan sosial berskala besar yang dilakukan oleh pemerintah. Sebelum adanya pandemic covid-19 terdapat 14 sektor yang mendorong pertumbuhan PDB Nasional yaitu sektor 
Pertambangan dan Penggalian; Industri Pengolahan; Pengadaan air, pengelolaan sampah, limbah dan daur ulang; Konstruksi; Perdagangan Besar dan Eceran; Transportasi dan Pergudangan; Penyediaan akomodasi dan makan minum; Informasi dan Komunikasi; Jasa Keuangan dan Asuransi; Real Estate; Jasa Perusahaan; Jasa Pendidikan; Jasa Kesehatan dan Kegiatan Sosial; Jasa Lainnya. Sepuluh sektor tumbuh relative cepat yaitu sektor Pengadaan air, Pengelolahan Sampah, Limbah dan Daur Ulang; Konstruksi, Transportasi dan Pergudangan; Penyediaan akomodasi dan Makan Minum; Informasi dan Komunikasi; Jasa Keuangan dan Asuransi; Jasa Perusahaan; Jasa Pendidikan; Jasa Kesehatan dan Kegiatan Sosial dan Jasa Lainnya. Tujuh sektor yang memiliki keuntungan lokasional yaitu sektor Industri pengolahan; Perdagangan besar dan eceran; Konstruksi; Penyedia Akomodasi dan Makan Minum; Real Estate dan Jasa Pendidikan.

Sedangkan saat terjadi pandemi Covid-19 terdapat 8 sektor yang mendorong perumbuhan PDB Nasional yaitu sektor Pertanian, Kehutanan dan Perikanan; Pengadaan air, pengelolaan sampah, limbah dan daur ulang; Informasi dan Komunikasi; Jasa Keuangan dan Asuransi; Real Estate; Administrasi Pemerintahan, Pertahanan dan Jaminan Sosial; Jasa Pendidikan; Jasa Kesehatan dan Kegiatan Sosial. Tujuh sektor tumbuh relative cepat yaitu sektor Pertanian, Kehutanan dan Perikanan; Pengadaan Air, Pengelolaan Sampah, Limbah dan Daur Ulang; Informasi dan Komunikasi; Jasa Keuangan dan Asuransi; Real Estate; Administrasi pemerintahan, pertahanan dan Jaminan sosial; Jasa Pendidikan; dan Jasa Kesehatan dan Kegiatan Sosial. Dan enam sektor yang memiliki keuntungan lokasional yaitu sektor Industri Pengolahan; Pengadaan Air, Pengelolaan Sampah, Limbah dan Daur Ulang; Transportasi dan Pergudangan; Penyediaan Akomodasi dan Makan Minum; Real Estate; Jasa Pendidikan.

\section{DAFTAR PUSTAKA}

Agma, S. F. (2015). Peranan Foreign Direct Investment Terhadap Pertumbuhan Ekonomi Indonesia. Jurnal Ilmiah, 1-14.

Basuki, A. T., \& Prawoto, N. (2015). Analisis Komposisi Pengeluaran Publik Terhadap Pertumbuhan Ekonomi dalam Mendukung Good Governance dalam Memasuki MEA (Studi Empiris Provinsi di Indonesia Tahun 2010-2014). Book of Proceedings Published by Universitas Negeri Padang, c, 1-19. http://fe.unp.ac.id/\%0Ahttp://fe.unp.ac.id/sites/default/files/unggahan/1. Agus Tri Basuki\%2C Nano Prawoto \%28hal 1-19\%29_0.pdf

BPS Provinsi Jawa Timur. (2019). Pertumbuhan Ekonomi Jawa Timur Tahun 2018. Badan Pusat Statistik

BPS Provinsi Jawa Timur. (2021). Provinsi Jawa Timur Dalam Angka 2021. Badan Pusat Statistik.

DRS. ROBINSON TARIGAN, M. R. P. (2014). EKONOMI REGIONAL ( REVISI ). BUMI AKSARA. 
Estuningtyas, R. D. (2018). Dampak globalisasi pada politik, ekonomi, cara berfikir dan ideologi serta tantangan dakwahnya. Al-Munzir, 11(2), 195-218.

Fatmawati, I. (2015). Analisis Pertumbuhan Ekonomi Indonesia Dengan Model Solow Dan Model Schumpeter Jurnal Ilmiah. Jurnal Ilmiah Mahasiswa FEB. https://jimfeb.ub.ac.id/index.php/jimfeb/article/view/1860

Hajeri, H., Yurisinthae, E., \& Dolorosa, E. (2015). Analisis Penentuan Sektor Unggulan Perekonomian di Kabupaten Kubu Raya. Jurnal Ekonomi Bisnis Dan Kewirausahaan, 4(2), 253. https://doi.org/10.26418/jebik.v4i2.12485

Jhingan, M. L. (2014). The Economics of Development and Planning. In Pt Rajagrafindo Persada.

Margunani. (2002). Pengaruh Output Sektor Pertanian Terhadap Produk Domestik Bruto Propinsi Jawa Tengah. Dinamika, 11(2), 57-70.

Perencanaan, K., Nasional, P., Republik, B., Abstraksi, I., Baru, N., Pembangunan, R., Menengah, J., Kunci, K., Journal, T. I., Planning, D., \& Iv, V. (2020). Covid-19, New Normal, dan Perencanaan Pembangunan di Indonesia. Jurnal Perencanaan Pembangunan: The Indonesian Journal of Development Planning , 4(2), 240-252. https://doi.org/10.36574/jpp.v4i2.118

Primadhana, W. P., \& Wahed, M. (2020). Strategi Percepatan Investasi Kota Surabaya. Jurnal Economic Resource, 2(2), 147-162. https://doi.org/10.33096/jer.v2i2.427

Purnamasari, S. (1992). Ekonomi Pembangunan (Pengantar Ekonomi Pembangunan) (Vol. 5, Issue 1).

Tumangkeng, S. (2018). Analisis Potensi Ekonomi Di Sektor Dan Sub Sektor Pertanian, Kehutanan Dan Perikanan Kota Tomohon. Jurnal Berkala Ilmiah Efisiensi, 18(01), 127-138.

Widjajanto, T., \& Agus, I. (2020). Analisis Pengaruh Investasi dan PDRB Terhadap Peyerapan Tenaga Kerja di Provinsi Jawa Tengah Tahun 2018. Sosio E-Kons, 12(1), 89. https://doi.org/10.30998/sosioekons.v12i1.5846

Yasa, I. N. M. (2011). POTENSIAL KABUPATEN KLUNGKUNG diterapkan di setiap daerah akan berbeda antara daerah satu dengan daerah yang. Jurnal Ekonomimi, 1-21. 